
2007

\title{
IDENTIFICATION AND ASSESSMENT OF CRETAN GEOTOPES
}

\author{
Fassoulas C. ${ }^{1}$, Paragamian $\mathrm{K}^{2}{ }^{2}$, and Iliopoulos $\mathbf{G} .{ }^{1}$ \\ ${ }^{1}$ Natural History Museum of Crete, University of Crete, Irakleion 71409, Crete, Greece, \\ fassoulas@nhmc.uoc.gr,gi6@nhmc.uoc.gr \\ ${ }^{2}$ Hellenic Institute of Speleological Research, P.O. Box 2240, Irakleion 714 09, Crete, Greece, \\ paragam@otenet.gr
}

\begin{abstract}
This study presents the first complete list of the most important geological features and landforms of Crete. Identification of geotopes and collection of data were based on earlier publications and similar efforts, search in existing scientific literature and field observations. A database was formed containing the overall documentation of each geotope, on which evaluation was afterwards implemented. Worldwide tested methodologies were used for the recognition of the importance and value for each geotope, as well as, the identification of possible threats and future perspectives for local economic and scientific development. About 132 geotopes were recognized for their national or regional importance, their representativeness for the interpretation of Cretan geology and impact on natural ecosystems and local culture. The majority of these geotopes are of high scientific and aesthetic value serving in our days tourist and scientificleducational purposes. Generally no serious threats or dangers have been recognized, except of few caves where the impact of massive tourism is serious. These results set a minimum base for the conservation and enhancement of Cretan earth heritage, that should be followed by nationally based actions for further recognition and legal protection of our geodiversity.
\end{abstract}

Key words: Geotopes, geodiversity, earth heritage, geoconservation, Crete.

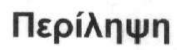

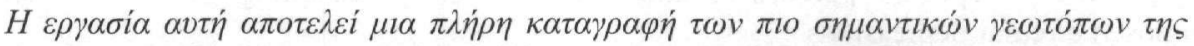

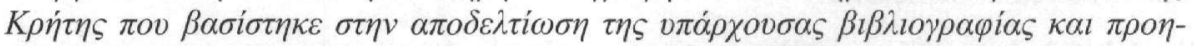

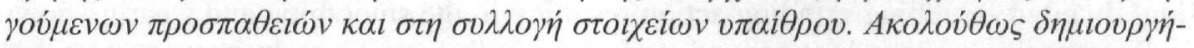

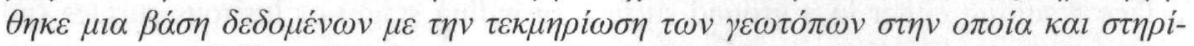

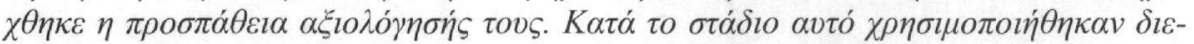

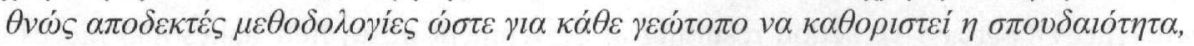

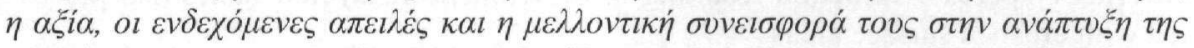

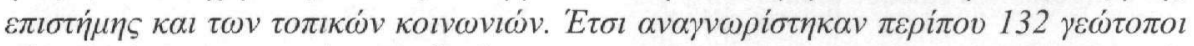

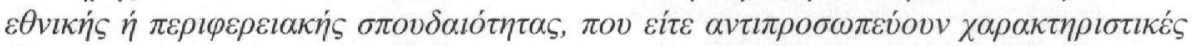

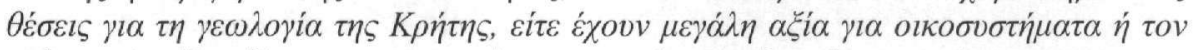

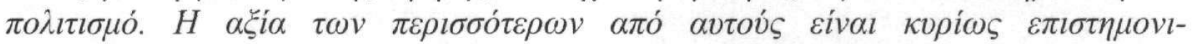

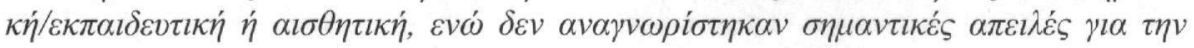




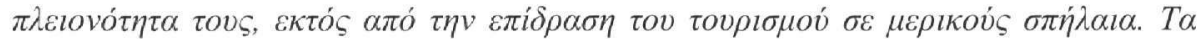

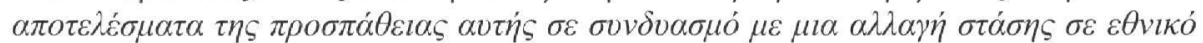

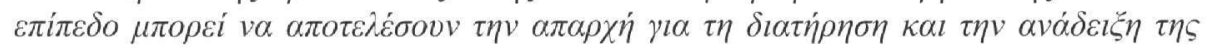

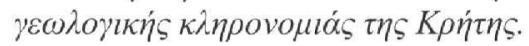

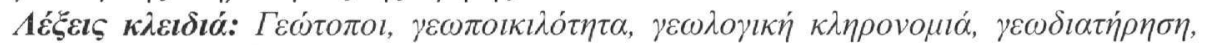

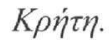

\section{Introduction}

The geological environments are commonly regarded by geologists as sites with only scientific or economic importance. However, their involvement in the environment of the Earth is as vital as other important resources, like water or oxygen. Not only plants and animals are directly dependent on the geological foundation, but also humans are affected by the surrounding geological environment (Fassoulas 2001). Landscape, rocks and soils not only provide elements and raw materials for our economy, but also affect significantly human temper and culture.

Ancient Greek civilizations are some of the most outstanding examples of how natural and geological phenomena have been part of human history and culture. Greek mythology offers some relevant examples presented earlier by Mariolakos (2001). The great cataclysm in the Bible is another international example of a past geological process that had an enormous effect on the human history (Ryan and Pitman, 2000). It is thus apparent that the geological environment of an area is part of its heritage; it's the so-called geological or earth heritage (Gray 2004).

The pure geological context of the earth heritage of an area is usually referred as geodiversity. The term geodiversity was recently induced in the international literature in an effort to describe, in the same way that biodiversity does, the wide natural range (diversity) of geologic (rocks minerals, fossils), geomorphologic (landform processes) and soil features, including their assemblages, relationships, properties, interrelations and systems (Gray 2004). Although abiotic environment is one of the main parameters of nature, the degree of its conservation globally is much lower compared to biodiversity. Many international nature conservation organisations used the term "nature conservation" to refer mainly to the "wild life" conservation, focusing most of their attention on the latter (Milton 2002). However, geological and geomorphologic conservation efforts in Europe, Australia and other places worldwide started about a century ago focusing either on landforms and geological formations or on structures that occur in certain geological sites (Gray 2004). This has led to the recognition of the geosites or geotopes (the term that comes from the ancient Greek words $\gamma \alpha i \alpha=$ geo and $\tau o ́ \pi \circ \varsigma=$ tope $=$ site, which we shall use in concordance with the ecotopes) that constitute the geodiversity of an area.

Therefore, it is crucial for a territory to identify its geological heritage and recognize its indubitable value. This article deals with the wealthy geodiversity of Crete island in the south Aegean (Fig. 1). It presents the identification and assessment of the most important geotopes of the island, as well as some thoughts for their conservation and enhancement.

\section{Conserving and Assessing geodiversity}

\subsection{Assessing geodiversity's value}

The question that arose decades ago, why we should conserve biodiversity and nature in general, is the starting point to discuss the possible or real value of geodiversity. Furthermore, nowadays it is clearly demonstrated (Ellis et al. 1996) that: natural landforms create the environments within which the diverse flora and fauna live; rocks provide the soil and influence the drainage conditions of biological habitats; biological and geological forms and functions are inextricably linked to create a series of natural ecosystems of immense richness and diversity. 


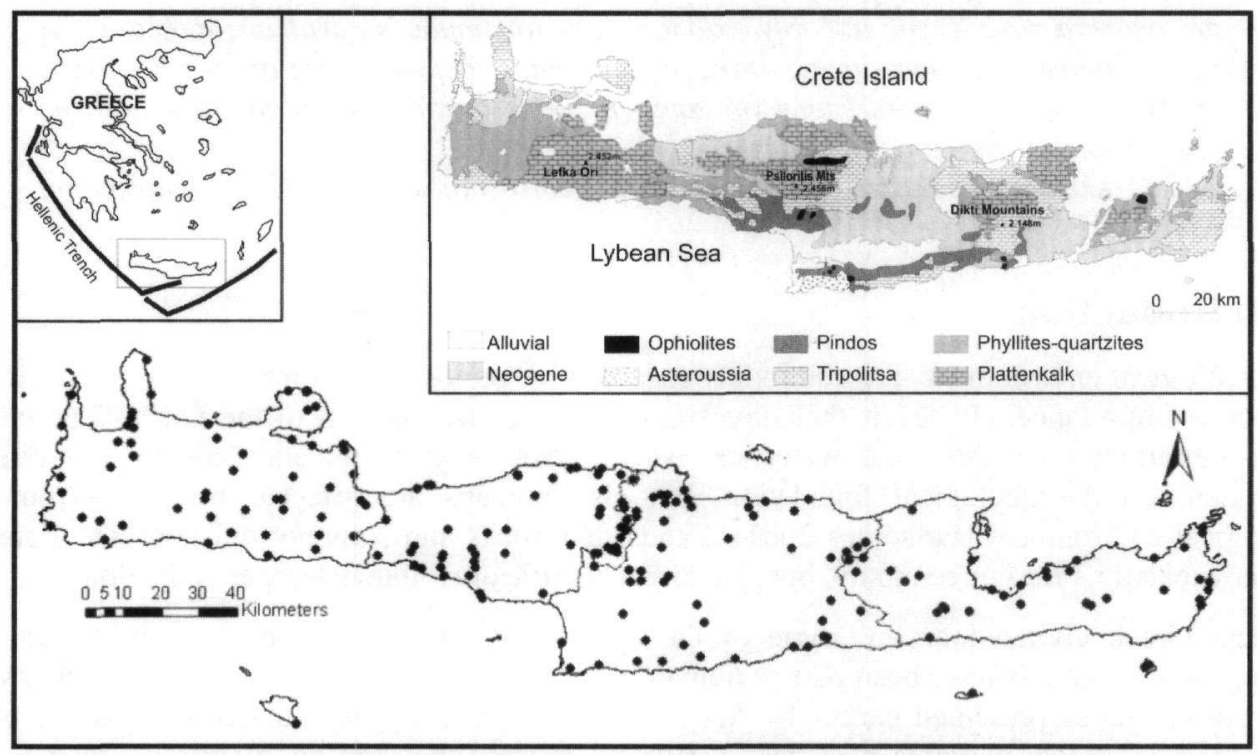

Figure 1 - Distribution of considered geotopes in the four Cretan prefectures. In the embedded figures a general geological map of cretan nappes based on Creutzburg et al. (1977) and the location of study area

Hence, the determination of geodiversity's value in a territory assigns its degree and importance as an economic resource. Although the value of nature or the rationale of nature conservation was studied by many organizations and scientists (see Nature Conservancy Council 1984 and Constanza et al. 1997), the way to value geodiversity has recently been outlined (Ellis et al. 1996). Several approaches have been presented in the literature, however, the most comprehensive and expanded one (Gray 2004) classifies the value of each geotope into six groups: intrinsic or existent; cultural; aesthetic; economic; functional; and research or educational one. This value can further demonstrate the international significance, the exceptional nature, the representativeness of features and the contribution to environmental forecasting for each geotope.

In Greece, only a few studies focused on the assessment of geological heritage have been implemented till now and these are related with the management of the two European and UNESCO Global Geoparks of Greece (Fassoulas and Skoula 2006, Zouros 2005).

\subsection{Conservation practices}

Many examples can be presented for a successful recognition and conservation of the geological heritage around the world. The English Nature, the Countryside Council of Wales and the Scottish Natural Heritage have contacted since 1990 a project for the inventory and assessment of British geological heritage (Ellis et al. 1996). In England it resulted into the designation of about 500 areas as Sites of Special Scientific Interest (SSSI) and much more as Regionally Important Geological/Geomorphological Sites (RIGS), managed and conserved under the special Geodiversity Action Plans (English Nature et al. 2003).

International organisations such as the International Union for the Conservation of Nature (IUCN), UNESCO and the International Union of Geo-Sciences (IUGS) have established certain projects to include geodiversity to their nature conservation policies. More specifically, UNESCO presented an initiative called Geoparks to enhance the value of nationally important geological sites, while IUGS together with UNESCO established in 1995, the project Geosites to compile a global list of the world's most important geological sites. The latter has recently resulted in a list of the most important geological sites of south-eastern Europe (Theodosiou-Drandaki et al. 2004). 
A new initiative, the European Geoparks Network, was created in 2000 through the LEADER program by four European territories (Spain, France, Germany and Greece) and was immediately put under the auspices of UNESCO and later was accepted by the organisation as a model for the other continents. The initiative aims to manage both abiotic and living nature, including cultural heritage, in certain European territories in order to achieve high standards of conservation, promotion and finally true economic development (Zouros and Martini 2003). Two territories from Greece, Lesvos Petrified Forest and Psiloritis Natural Park in Crete are currently members of this network.

Despite all this progress on the conservation of geological heritage worldwide, in Greece the existing legislation for the conservation of Nature actually do not permit any recognition and further conservation of geotopes (Fassoulas 2004). The only geological monument protected by law is the Lesvos Petrified Forest, whereas other monuments such as Olympus Mt or Samaria Gorge are protected as National Parks because of their ecologic value (Zouros and Fassoulas 2006). Meteora in Thessaly, on the other hand, are included in UNESCO's World Heritage List but only as a cultural monument due to the monasteries. Furthermore, funding of geo-conservation under National or European funds is impossible, because only the living and human environment is regarded as Nature!

However, several studies have been published to catalogue and promote geological heritage of Greece. The most comprehensive are the Atlas of Geological Monuments of Aegean (Mountrakis et al. 2002) and the Natural Monuments of Greece (Bornovas, 1999), whereas several others are focused on smaller regions or territories (Ewing-Rassios 2004, Fassoulas 2000, Zouros 2000)

\section{Materials and Methods}

\subsection{Identification and monitoring of Cretan geotopes}

A first attempt to identify and map Cretan geotopes was undertaken by the Natural History Museum of Crete in 2000 (Fassoulas 2000). During that study more than 48 geotopes were recognised and described, whereas some of those were later listed in the Atlas of Geological Monuments of Aegean (Mountrakis et al. 2002), while, the most important of those were also included in the IUGS "Geosites project" inventory (Theodosiou-Drandaki et al. 2004). Using that study as a starting point we have re-explored the island of Crete to identify and map new geotopes, re-filtered the existing literature for geological formations and palaeontological sites, and discussed further with local authorities and inhabitants. Useful tools in this effort were the published field guides (Kuss 1980, Meulekamp et al. 1979, Papanikolaou 1988), the reports and lists of karstic features (Faure, 1996, Platakis, 1975) and other synthetic publications (Bornovas 1999). Furthermore, for central Crete the database of Psiloritis European Geopark was also used (Fassoulas and Skoula 2006).

For each site we collected geographical information, data about the nature and character of the site, geological and literature descriptions, environmental issues, human activities in the broader areas (which refer to traffic for the case of neighbouring with highways or heavy traffic roads; tourism for all touristic activities; watering for water supply and irrigation purposes; agriculture for pasturing or cultivations; mining for occurrence of active quarries etc.; or sports for hiking, and other extreme sport activities) and any other related information. Data were documented and stored in a database and were later categorized into several main categories according to their nature and character; i.e. Landforms, Lithologies, Faults, Folds, Caves and Karst, Fossil sites, Hydrology and Mining features (Figs 2a-d). 


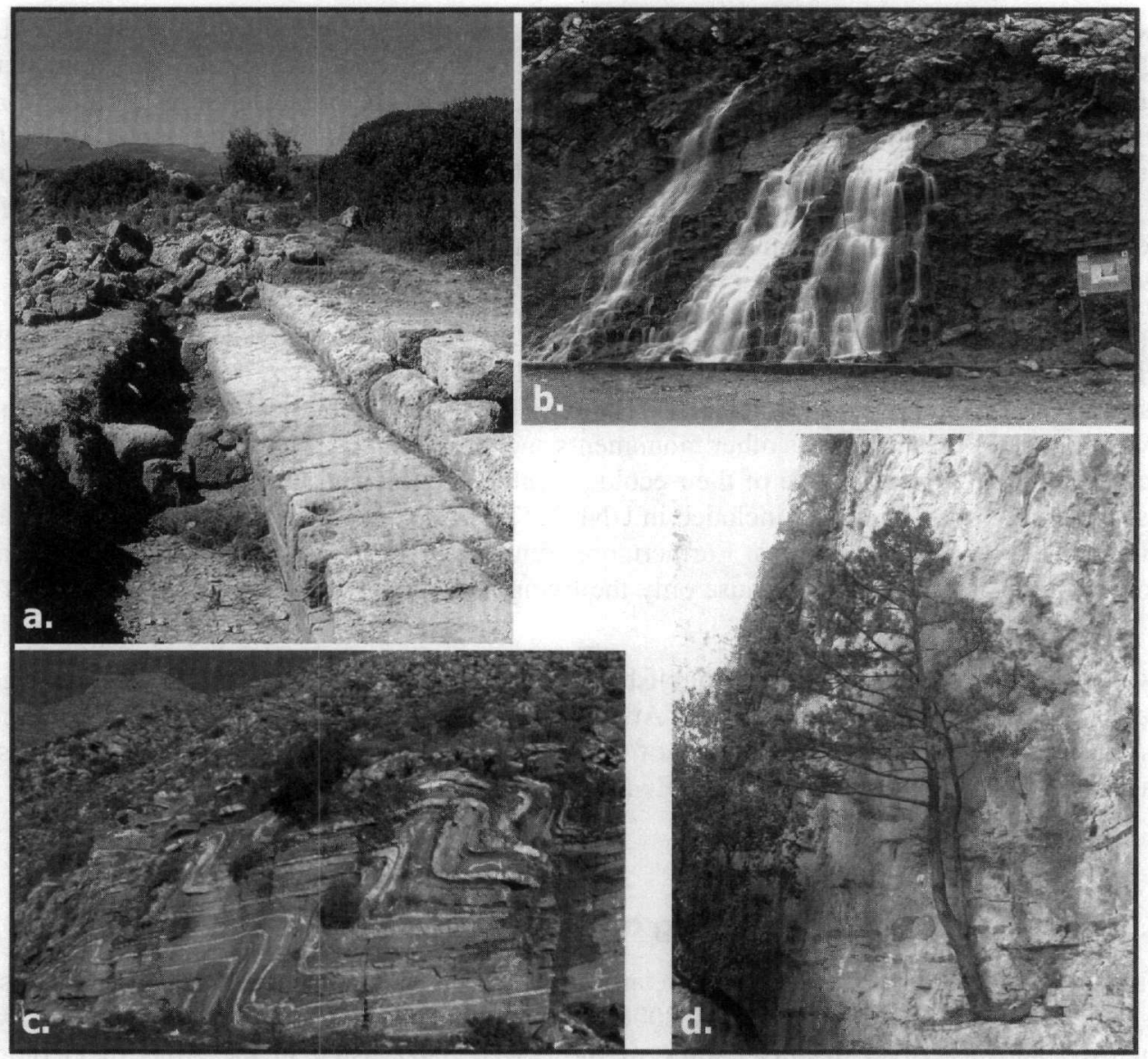

Figure 2 - a. Ancient Falasarna harbour at the western coast risen about 6 meters over present sea level; b. Part of the Talea Ori stratigraphic section in Rethymno with a seasonal karstic spring in stormatolitic dolomite of Plattenkalk nappe and an information panel of Psiloritis Geopark; c. Vossakos fold succession in plattenkalk in Vossakos area, Rethymno; d. Imbros gorge in Hania with rich flora

This inventory finally resulted into the identification of about 195 geotopes all over Crete and the surrounding small islands (Fig. 1). These do not include all the known gorges or karstic structures of the island, which are abundant (Fassoulas et al. 2004, Platakis 1975).

Hence, only the most scientifically important and beautiful gorges, karstic depressions and caves are included in the list. It is worth mentioning that in Crete more than 6,000 caves and other karstic depressions have been recognised till now (Paragamian, unpublished data) and sufficient data for their condition and importance exist for nearly 800 of them. Earlier studies (Faure 1996, Platakis 1975, Schmalfuss et al. 2004, Sket et al. 2004) were used to filter this huge information and additional data collected. Finally, about 32 caves have been used for this study.

After a first evaluation only the most important geotopes are discussed here, comprising those of Regional and National value only. The list comprises about 132 geotopes, 39 of them located in Hania prefecture, 39 in Rethymno, 30 in Irakleio and 24 in Lasithi prefecture (Appendix I).

\subsection{Assessment procedure}

At a first level of assessment we classified the Cretan geotopes according to their overall importance in Local, Regional and National (Appendix I). Our evaluation of Cretan geotopes was 
based on the criteria presented in earlier studies after their adaptation to the Cretan situation (Ellis et al. 1996, Zouros 2005).

Thus, the main criteria used were their importance for the national or even international earth scientists, their representativeness for the interpretation of Cretan geology, their exceptional nature, their impact to the local and larger community, their significance for existing educational activities and any other existing designations. For the identification of the importance primarily of the national and secondary for the regional geotopes, additional criteria, such as the minimum duplication of interest between geotopes and the possibility for conservation, were considered as well.

The different kinds of value of each geotope (Gray 2004) were then determined based on its contribution to the local development and scientific process, the activities that are related with it, the potential future activities, its interaction with the broader natural environment and its influence to the local history and culture. The value was assigned as Aesthetic (mainly for tourist purposes), Scientific (for the scientific and educational activities), Economic (for contributing to the local economy), Natural (for its role to the establishment of special environments) and Cultural (for their relation to history and culture).

Additionally, we proceeded in a preliminary recognition of threats and dangers that geotopes may face. These may result from natural processes, such as weathering and erosion, or from human activities. Determination uses the colour scale with green for a secure situation, yellow for minor threats or dangers and red for very serious or direct threats. Of course this evaluation gives only a general overview of the conservation status and do not replace the required Special Environmental studies or management plans, which exist only for some larger areas (Agios Dikaios, Lefka Ori, Psiloritis, Kedros, Asteroussia, Dikti mountains) and Samaria National Park.

\section{Results}

\subsection{Evaluation of Cretan geotopes}

The above presented study resulted into the first complete database of Cretan geotopes hosted in the Natural History Museum of Crete Collections and Databases (Fig. 3). A first attempt for a rough assessment of the protection status of each geotope was also undertaken based in the collection of all the existing data and references. This assessment needs further improvement and re-examination under a wider reference level, combining all potential changes in conservation status and human activities in the surrounding areas, the planning policies of local and regional authorities, as well as the local development priorities. Such studies however, require time, political support and funding, issues that were out of the purposes and limitations of this study.

Nevertheless, it was revealed that from the approximately 195 Cretan geotopes and the abundant karstic features, 48 are at least of National importance (not excluding the case that some might be of international importance as well), 84 are of Regional importance and the rest of Local importance. Among the geotopes of National importance lie the well known Samaria Gorge and Vai palm valley, the three archaeological caves of Idaion and Diktaion Andro and Kamares, the Gourgouthakas, the deepest cave in Greece and among the list of the 30 deepest caves in the world, the Lassithi plateau, the exposure of Cretan detachment fault in Agios Fanourios, the Ierapetra active fault, the Agios Pavlos folds, the Asteroussia rocks, the Ravdoucha beds as the base of Tripolitsa nappe, the Talea Ori stratigraphic section (Fig. 2b) for the preservation of the whole Plattenkalk sequence, the well-preserved in metamorphic rocks Fodele fossils, the Makrilia paleoflora, the uplifted ancient harbour in Falassarna (Fig. 2a) and many others. 


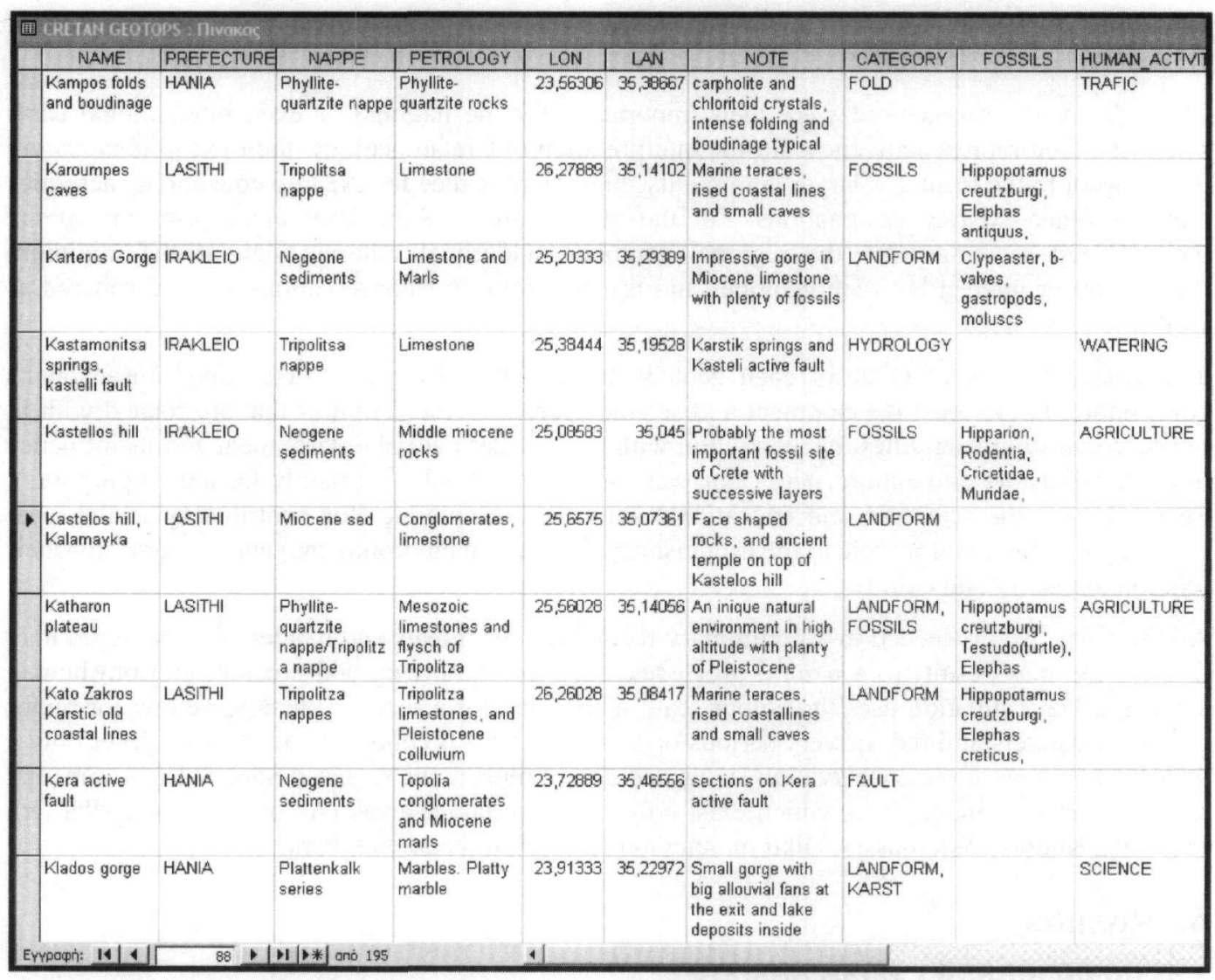

Figure 3 - An example of the complete database created under this study for the documentation and evaluation of Cretan geotopes

Of Regional importance (Figs 4a-d) are the Ravdoucha mines, the Agia lake, Omalos and Katharo plateaus, Preveli and Klados gorges, Voulismeno Aloni doline, Sfentoni and Simonelli caves, Kalamayka's meteora (Fig. 4c), Lastros active fault, Kalavros beds, Psiloritis metaflysch, Pantanasa section etc.

The majority of these geotopes are in a secure condition as regard to the conservation and protection status. Many of these geotopes are inaccessible, isolated or far away from disturbing human activities. Thirty three of them however face conservation problems or protection threats that might change in worse in future. These are induced due to weathering and erosion processes, quarrying activities, exhaustion of natural resources, massive tourism and the accompanying problems that it causes. Two representative examples can be presented: the case of Agia Lake in Hania that was totally exhausted in 2005 due to overpumping, and the Samaria gorge that accepts about 2000 visitors per day in summer months increasing the possibility for forest fire and accelerating erosion. In some geotopes of local importance serious threats exist related in most cases with land movements at road cuts or coastal areas.

Additionally, caves are the most vulnerable geotopes as they are small areas with unique characteristics (fragile speleothems, unique populations of endemic animal species, bat colonies, archaeological and palaeontological findings) and in most cases suffer from disturbances imposed by uncontrolled human visitations, vandals, etc. Four caves, i.e. Diktaion Andon, Milatos, Agia Paraskevi and Labyrinthos are facing serious problems because of those reasons. 


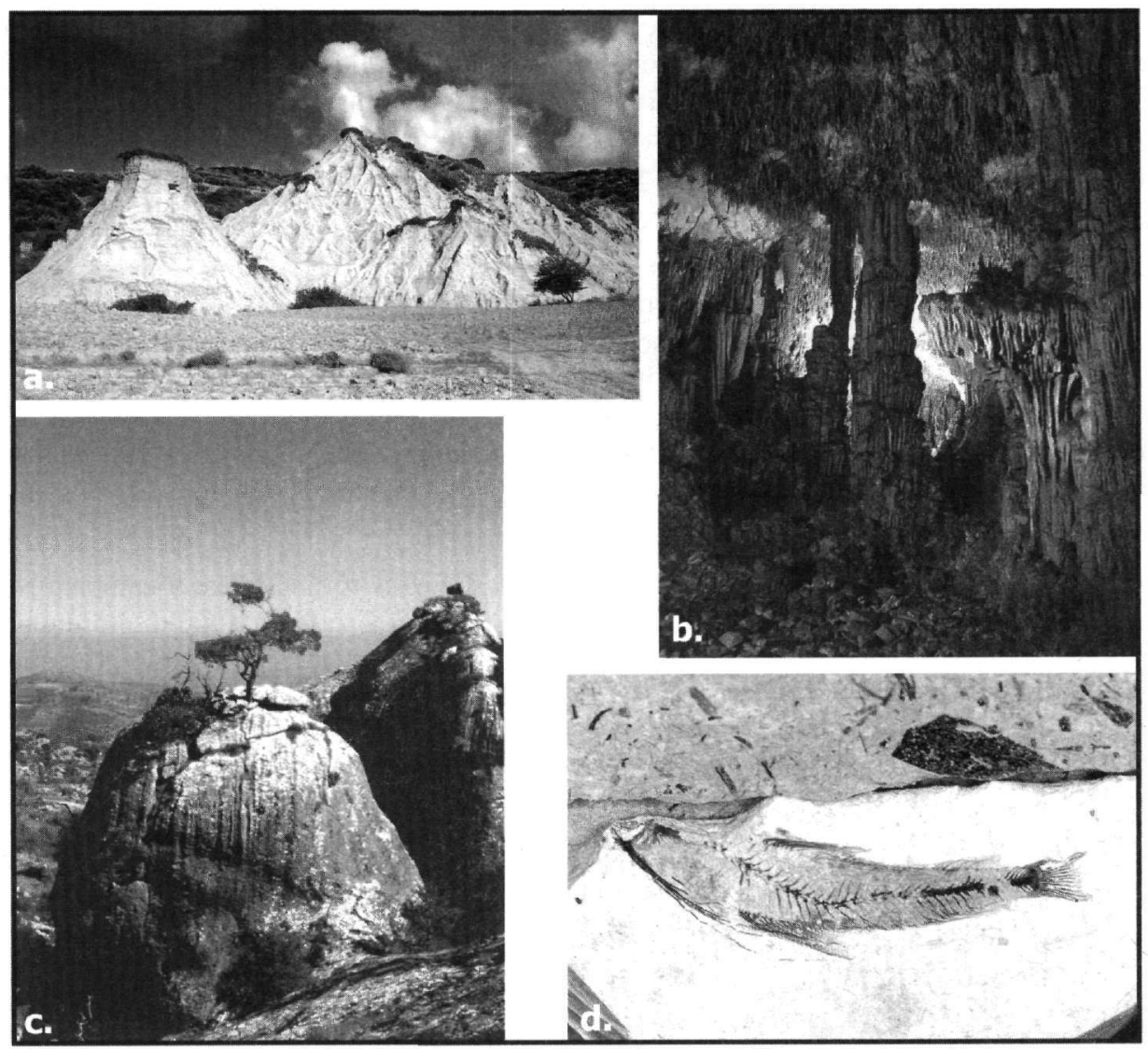

Figure 4. a. Potamida's "nunes" landform in siltstone in Hania prefecture; b. Arkalospilios cave in Rethymno; c. Meteora, made of Miocene breccia at Kalamayka area, Lasithi prefecture; d. Prassas' fossil site in diatomites in Irakleio

Finally, about $38 \%$ of the evaluated geotopes appear to have high aesthetic value that would enhance geo-and eco-touristic activities (Figs 2, 4). The same percent of geotopes have a high scientific/educational value and about $5 \%$ both scientific and aesthetic value. Several geotopes of high cultural value (as is the case of several caves) have also been recognised and few others are of natural/environmental or economic value.

\subsection{Perspective}

The Nobel poet laureate S. Heaney has emphasised that "...if chemistry tells us from what our Earth was made of and physics of how it was build, geology definitely tells us how it will be." (Parkes 2004). His words draw clearly a main reason why our earth heritage should be conserved; the ability that only geology among the other disciplines has to predict the evolution of physical processes. Hence, the individual or exceptional geological features should not only be protected for the benefit of natural ecosystems and future generations but also for the further development of science.

There is indeed a fascinating story to tell that is of profound relevance to the world recorded in rocks and landforms, however some chapters are still far from complete. It is thus vital that the important rocks and landforms must be protected in order to be able to provide the necessary scientific resource for future work, including the possibility to utilise new scientific techniques that have not been discovered yet (Ellis et al. 1996). 
The identification of the existing geotopes in Crete as a whole area is the first step for the recognition of its earth heritage and additionally the determination of its geodiversity. The list of the Cretan geotopes presented in this article is the first complete attempt to recognise the geological heritage of the island. Although legislation and existing public ethics do not permit a legal protection for the geotopes, this effort probably can put the first stone for their conservation.

At a first level, the list presents the most important, from scientific and educational point of view, of the Cretan geotopes setting the base for their potential future protection and conservation. Besides, it offers the possibility to local authorities to identify their local geological heritage and encompass it in their plans, serving also for public awareness and sensitisation through a combination of activities. The examples of how the European Geoparks work for the protection and conservation of geological heritage through educational and geotouristic activities is a secure way to start. Globally gained experience offers tools for site protection, conservation measures and enhancement policies that are always necessary for the economic support of any initiative undertaken.

It is probably worthwhile the academic institutions or societies to undertake a campaign for the identification and evaluation of the most important geotopes of Greece that will build the base for a further legal recognition of our geological heritage and subsequent for their protection and conservation that is a necessity in Greece. As a model, the British example for the recognition of Sites of Special Scientific Interest can be used. Although the British case considered both bio- and geo-diversity, the already successful NATURE 2000 network has worked well with bio-diversity all over Europe, covering the case of living environment.

Furthermore, such an effort will strengthen and support the geoconservation initiatives in Greece, in the way that it can change the existing outlook of geodiversity in higher state level and authorities. It is essential to share funds for geodiversity too under the environmental or nature projects, in order to achieve a fundamental conservation and enhancement status for our earth heritage

\section{Conclusions}

Modern trends for the conservation of environment induce a holistic approach for nature protection based on the continuously manifested confirmation for the vital interactions of abiotic and living environments. Such an approach presumes the protection and conservation of geological foundation in each ecosystem and environment that additionally sets the prerequisite for the identification of geological environment. Complementary, it is broadly recognized that important geological features and landforms should be conserved to serve for future scientific research and utilization of new scientific methodologies, strengthening thus the ability that only geology has among other disciplines, to predict the development of natural processes.

This study focuses primarily on the identification of Cretan geotopes and secondary on the assessment of their value, facing threats and future perspectives, as a base for their recognition and further protection. Worldwide tested methodologies were used for the inventory and recording of the most important geological formations, structures and landforms of the island, as well as for their assessment. Elaboration of data resulted in the recognition of about 132 geotopes of regional and national importance that were further studied for their value and influence to the local environment and society.

The majority of the 48 nationally important geotopes have high scientific value and many of them an outstanding aesthetic appeal; whereas, several have a significant impact to local ecosystems and culture. Most of these geotopes do not face serious threats or danger, quite a few may face some threats in future, while three caves are already under serious threats, as a result of massive tourism and human activities. The rest geotopes are of regional importance for their representativeness for the interpretation of Cretan geology, for their contribution to local scientific, training or cultural 
activities or for their impact to natural ecosystems. In this case, the majority of geotopes are of high scientific and aesthetic value, many of them have direct impact to local economy either through mining or touristic activities, while few of them are important for ecosystems and culture of the island. About 25 geotopes of central Crete constitute the Psiloritis Natural Park, the one of the two European and UNESCO Global geoparks of Greece.

This first attempt for a complete identification of Cretan geotopes is a minimum contribution for the recognition and protection of the earth heritage of the island. It serves however, as a useful tool for local authorities and scientific community, for a further development of geoconservation, increase of public awareness and sensitization and enhancement of our geodiversity. Further advance and action is required in national level to achieve higher recognition and better legal protection of our earth heritage.

\section{Acknowledgments}

The authors would like to thank Dr V. Melfos and an anonymous reviewer for their critical comments and suggestions, which improved text appearance. Mr Nikolakakis M. is also thanked for his assistance in the preparation and visualization of database.

\section{References}

Bornovas, I., 1999. The Natural Monuments of Greece. Kaktos Publ., Athens, 347pp.

Constanza, R., d'Arge R., de Groot, R., Farbeck, S., Grasso, M., Hannon, B., Limburg, K., Naeem, S., O’Neill, R.V., Paruelo, J., Raskin, R.G., Suttonkk, P., and van den Belt, M. 1997. The value of the world's ecosystem services and natural capital, Nature,387, 253-260.

Creutzburg, N., Drooger, C.W., Meulenkamp, J.E., Papastamatiou, J., Seidel, E., and Tataris. A., 1977. Geological map of Crete (1:200.000). IGME, Athens

English Nature, Quarry Products Association and Silica and Moulding Sands Association 2003. Geodiversity and the Mineral Industry - Conserving our Geological heritage, Entec UK Ltd., 20pp.

Ellis, N.V. (ed), Bowen, D.Q., Cambell, S., Knill, J.L., McKirdy, A.P., Prosser, C.D., Vincent, M.A., and Wilson, R.C.L., 1996. An introduction to Geological Conservation Review, GCR Series, No. 1, Joint Nature Conservation Committee, Peterborough, 131pp.

Ewing-Rassios, A., 2004. A geologist's guide to western Macedonia, Greece, Grevena Development Agency, 120 pp.

Fassoulas, C., 2004. Psiloritis Geopark: Protection of geological heritage through development. In M.A. Parkes (ed.) Natural and Cultural Landscape - The geological foundation, Royal Irish Academy, Dublin, 291-294pp.

Fassoulas, C., 2001. Protection and promotion of geological monuments in Crete. In N. Zouros (ed.), $3^{d}$ Inter. Congr. for Management of Protected Areas and Natural Monuments, Lesvos, $127-142 \mathrm{pp}$.

Fassoulas, C. 2000. Field Guide to the Geology of Crete, Natural History Museum of Crete Publ., Irakleion, pp.104.

Fassoulas, C., and Skoula, Z., 2006. Assessing the economic value of the Psiloritis area through the European Geoparks Network initiative. In: VIII Inter. Conf for the Protection and Restoration of Environment, Hania, Crete, Proc. vol., T.11, 8pp. 
Fassoulas, C., Nikolakakis, M., and Paragamian, K., 2004. Geomorphologic and tectonic features of Cretan gorges, Crete, Greece, $5^{\text {th }}$ Inter. Symp. Eastern Mediterranean Geology, Proc. Vol., 1, 415-418.

Faure, P., 1996. Sacred caves of Crete. Irakleion, 258pp.

Gray, M., 2004. Geodiversity: valuing and conserving abiotic nature, J. Wiley andSons, Ltd, New York, 434pp.

Kuss, S.E., 1980. Führer Zur Kreta-Exkursion, Des geologisch-paläontologischen Institutes der Universität Freiburg/BR, 51pp.

Mariolakos, I., 200. The physio-geological roots of the ancient-greek civilization and their enhancement through the organization of geomythological parks and geomythological trails. In N. Zouros (ed.), Management of Protected areas and Natural Monuments, Proc. Vol., Lesvos 1998, 67-97pp.

Meulenkamp, J.E., Dermitzakis, M., Georgiadou-Dikaioulia, E., Jonkers, H.A., and Boeger, H., 1979. Field guide to the neogene of Crete, Publications of the departement of Geology and Paleontology, University of Athens, series A., N. 32, 32pp.

Mountrakis, D., Zouros, N., and Soulakelis, N., 2002. Atlas of geological monuments of Aegean, Greece, Ministry of Aegean, Lesvos, 352pp.

Milton, K., 2002. Loving Nature: Towards an Ecology of Emotion, Routledge, London.

Nature Conservancy Council, 1984. Nature conservation in Great Britainm Nature Conservancy Council, Peterborough..

Papanikolaou, D.I., 1988. Introduction to the geology of Crete, IGCP Project N. 276 Field Meeting, Guide Book, 36pp.

Parkes, M.A., (ed.) 2004. Natural and Cultural landscapes - the geological foundation, Royal Irish Academy, Proc. Vol., Dublin 2002, Ireland, 329pp.

Platakis, E., 1975. Caves and other kartsic forms of Crete, Vol. B', Irakleion, Crete, 275pp.

Ryan, W., and Pitman, W., 2000. Noah's flood: The new scientific discoveries abut the event that changed history, Simon and Schuster (pubs). New York, 320pp.

Schmalfuss, H., Paragamian, K., and Sfenthourakis, S., 2004. The terrestrial isopods (Isopoda: Oniscidea) of Crete and the surrounding islands, Stuttgarter Beiträge zur Naturkunde, Serie A (Biologie) 662, 1-74.

Sket, B., Paragamian, K., and Trontelj, P., 2004. A census of the obligate subterranean fauna in the Balkan Peninsula. In: Griffiths H.I., Kryštufek B. and Reed, J. M. (eds). Balkan Biodiversity. Pattern and Process in Europe's Hotspot. Kluwer Academic Publishers, Dordrecht, The Netherlands, $367 \mathrm{pp}$.

Theodossiou-Drandaki, I., Nakov, R., Wimbledon, W.A.P., Serjani, A., Neziraj, A., Hallaci, H., Si jaric, G., Begovic, P., Petrussenko, Sv., Tchoumatchenco, Pl., Todorov, T., Zagorchev, I., Antonov, M., Sinnyovski, D., Diakantoni, A., Fassoulas, C., Fermeli, G., Galanakis, D., Ko utsouveli, A., Livaditi, A., Papadopoulou, K., Paschos, P., Rassiou, A., Skarpelis, N., Zouro s, N., Grigorescu, D., Andrasanu, Al., Hlad, Br., Herlec, U., Kazanci, N., Saroglu, F., Doga n, A., Inaner, H., Dimitrijevic, M., Gavrilovic, D., Krstic, B., and Mijovic, D., 2002. IUGS Geosites project progress - a first attempt at a common framework list for South Eastern Eu ropean Countries. In M.A. Parkes (ed.), Natural and Cultural Landscape - The geological foundation, Royal Irish Academy, Dublin, 81-89. 
Zouros, N., 2005. Assessment, protection and promotion of geomorphological and geological sites in the Aegean area, Greece, Géomorphologie: relief, processes, environment, n.3, 227-234.

Zouros, N., 2000. Guide to the Lesvos Petrified Forest Park, Natural History Museum of the Lesvos Petrified Forest Publ., Lesvos, 64pp.

Zouros, N., and Fassoulas, C., 2006. Geodiversity in Greek National Parks. In: $2^{\text {nd }}$ UNESCO Inter. Conf. on Geoparks, Belfast 2006, Abst. Vol., 62.

Zouros, N., and Martini, G., 2003. Introduction to the European Geoparks Network. In N. Zouros, G. Martini and M.L. Frey (eds), Proc $2^{\text {nd }}$ European Geoparks Network Meeting, Mytilene, Greece, 17-21.

Appendix I. Detailed list and documentation of most important Cretan Geotopes (for discussion see text)

\begin{tabular}{|c|c|c|c|c|c|c|c|c|c|}
\hline & Name & $\begin{array}{l}\text { Prefec- } \\
\text { ture }\end{array}$ & Lon & Lat & Category & $\begin{array}{l}\text { Human } \\
\text { Activities }\end{array}$ & $\begin{array}{c}\text { Impor- } \\
\text { tance }\end{array}$ & Value & $\begin{array}{c}\text { Con- } \\
\text { serva- } \\
\text { tion }\end{array}$ \\
\hline 1 & $\begin{array}{l}\text { Nopigia aragonite } \\
\text { marbles }\end{array}$ & Hania & 23.72139 & 35.51000 & Lithology & & National & $\mathrm{S}$ & Yellow \\
\hline 2 & $\begin{array}{l}\text { Plakalona detach- } \\
\text { ment }\end{array}$ & Hania & 23.73639 & 35.50417 & Fault & Traffic & National & $\mathrm{S}$ & Green \\
\hline 3 & Ravdoucha beds & Hania & 23.73389 & 35.54111 & Lithology & & National & $\mathrm{S}$ & Green \\
\hline 4 & Ballos rised bay & Hania & 23.58861 & 35.58194 & Landform & Tourism & National & $\mathrm{S}, \mathrm{A}, \mathrm{N}$ & Yellow \\
\hline 5 & Falassarna area & Hania & 23.56722 & 35.50917 & $\begin{array}{l}\text { Landform, } \\
\text { Fault }\end{array}$ & Tourism & National & $\mathrm{S}, \mathrm{A}, \mathrm{C}$ & Green \\
\hline 6 & Triassic evaporites & Hania & 23.56750 & 35.35222 & Lithology & Mining & National & $\mathrm{S}, \mathrm{E}$ & Yellow \\
\hline 7 & Elaphonisi area & Hania & 23.54167 & 35.27167 & Landform & Tourism & National & $\mathrm{A}, \mathrm{N}$ & Yellow \\
\hline 8 & Akrotiri section & Hania & 24.16750 & 35.55444 & Lithology & & National & $\mathrm{S}$ & Green \\
\hline 9 & Kourna lake & Hania & 24.27528 & 35.33083 & Hydrology & $\begin{array}{l}\text { Watering, } \\
\text { Tourism }\end{array}$ & National & $\mathrm{A}, \mathrm{E}, \mathrm{N}$ & Green \\
\hline 10 & Samaria Gorge & Hania & 23.96778 & 35.25528 & $\begin{array}{l}\text { Landform, } \\
\text { Karst }\end{array}$ & Tourism & National & $\mathrm{A}, \mathrm{N}$ & Yellow \\
\hline 11 & $\begin{array}{l}\text { Gigilos Beds, } \\
\text { Omalos } \\
\end{array}$ & Hania & 23.91944 & 35.29139 & Lithology & & National & S, A & Green \\
\hline 12 & Gonies section* & Irakleio & 24.92583 & 35.29528 & $\begin{array}{l}\text { Lithology, } \\
\text { Fault }\end{array}$ & Science & National & S, A & Green \\
\hline 13 & AImiros Spring* & Irakleio & 25.04667 & 35.33306 & Hydrology & Watering & National & $\begin{array}{l}\text { A, N } \\
\text { S, E }\end{array}$ & Yellow \\
\hline 14 & $\begin{array}{l}\text { Lavyrinthos cave, } \\
\text { Gortys }\end{array}$ & Irakleio & 24.89400 & 35.06500 & Cave & Tourism & National & $\begin{array}{l}\mathrm{S}, \mathrm{N} \\
\mathrm{C}, \mathrm{E}\end{array}$ & Red \\
\hline 15 & Asterousia Mts & Irakleio & 24.92944 & 34.95028 & Lithology & & National & $\mathrm{S}, \mathrm{A}$ & Green \\
\hline 16 & Matala caves & Irakleio & 24.75000 & 34.99500 & Landform & & National & $A, C$ & Green \\
\hline 17 & Fodele HP Fossils* & Irakleio & 24.91889 & 35.38333 & Fossils & Traffic & National & $\mathrm{S}$ & Green \\
\hline 18 & Kastellos hill & Irakleio & 25.08583 & 35.04500 & Fossils & Agriculture & National & $\mathrm{S}$ & Green \\
\hline 19 & $\begin{array}{l}\text { Arvi basalts and } \\
\text { radiolarites }\end{array}$ & Irakleio & 25.37694 & 35.00722 & Lithology & & National & $\mathrm{S}$ & Green \\
\hline 20 & Lasithi plateau & Lasithi & 25.46306 & 35.19667 & Landform & $\begin{array}{l}\text { Agriculture, } \\
\text { Tourism }\end{array}$ & National & $\mathrm{A}, \mathrm{E}$ & Green \\
\hline 21 & Ha Gorge & Lasithi & 25.83444 & 35.08528 & $\begin{array}{l}\text { Karst, } \\
\text { Fault }\end{array}$ & Watering & National & S, A & Green \\
\hline
\end{tabular}




\begin{tabular}{|c|c|c|c|c|c|c|c|c|c|}
\hline & Name & $\begin{array}{l}\text { Prefec- } \\
\text { ture }\end{array}$ & Lon & Lat & Category & $\begin{array}{c}\text { Human } \\
\text { Activities }\end{array}$ & $\begin{array}{l}\text { Impor- } \\
\text { tance }\end{array}$ & Value & $\begin{array}{l}\text { Con- } \\
\text { serva- } \\
\text { tion }\end{array}$ \\
\hline 22 & Hercynian rocks & Lasithi & 25.95000 & 35.16583 & Lithology & Traffic & National & $\mathrm{S}$ & Green \\
\hline 23 & $\begin{array}{l}\text { Kato Zakros Kar- } \\
\text { stic old coastal } \\
\text { lines }\end{array}$ & Lasithi & 26.26028 & 35.08417 & Landform & & National & $\mathrm{S}, \mathrm{A}, \mathrm{C}$ & Green \\
\hline 24 & $\begin{array}{l}\text { Diktaion Adron, } \\
\text { Psyhro }\end{array}$ & Lasithi & 25.44500 & 35.16278 & Cave & Tourism & National & $\begin{array}{l}\mathrm{A}, \mathrm{S} \\
\mathrm{N}, \mathrm{E}, \mathrm{C}\end{array}$ & Red \\
\hline 25 & Makrylia flora & \begin{tabular}{|l} 
Lasithi \\
\end{tabular} & 25.71306 & 35.06889 & Fossils & & National & $\mathrm{S}$ & Green \\
\hline 26 & Chrisi Island & Lasithi & 25.72000 & 34.87528 & Landform & Tourism & National & $\mathrm{A}, \mathrm{N}$ & Yellow \\
\hline 27 & Vai valey & Lasithi & 26.26389 & 35.25444 & Landform & Tourism & National & $\mathrm{A}, \mathrm{N}$ & Yellow \\
\hline 28 & $\begin{array}{l}\text { Agios Fanourios } \\
\text { detachment fault* }\end{array}$ & Rethymno & 24.87417 & 35.21417 & Fault & & National & S, A & Green \\
\hline 29 & Idaion Andro & Rethymno & 24.82861 & 35.20833 & Cave & $\begin{array}{l}\text { Tourism, } \\
\text { Science }\end{array}$ & National & $\mathrm{S}, \mathrm{N}, \mathrm{C}$ & Yellow \\
\hline 30 & Kamares cave* & Rethymno & 24.82754 & 35.17730 & Cave & & National & $\begin{array}{l}\mathrm{A}, \mathrm{S} \\
\mathrm{N}, \mathrm{C}\end{array}$ & Green \\
\hline 31 & $\begin{array}{l}\text { Sfentoni Cave, } \\
\text { Zoniana* }\end{array}$ & Rethymno & 24.83861 & 35.29833 & Cave & Tourism & National & \begin{tabular}{|l|}
$\mathrm{A}, \mathrm{S}$ \\
$\mathrm{N}, \mathrm{E}, \mathrm{C}$
\end{tabular} & Yellow \\
\hline 32 & Agios Pavlos Folds & Rethymno & 24.56222 & 35.10167 & Fold & Tourism & National & A, S & Green \\
\hline 33 & Gerani caves & Rethymno & 24.40694 & 35.35889 & Cave & $\begin{array}{l}\text { Tourism, } \\
\text { Science }\end{array}$ & National & $\begin{array}{l}\mathrm{A}, \mathrm{S} \\
\mathrm{N}, \mathrm{C}\end{array}$ & Yellow \\
\hline 34 & $\begin{array}{l}\text { Gerontospilios } \\
\text { cave, Melidoni* }\end{array}$ & Rethymno & 24.72944 & 35.38444 & Cave & Tourism & National & $\begin{array}{l}\mathrm{A}, \mathrm{S} \\
\mathrm{N}, \mathrm{C}, \mathrm{E}\end{array}$ & Yellow \\
\hline 35 & Vossakos folds* & Rethymno & 24.84611 & 35.35778 & Fold & & National & S, A & Green \\
\hline 36 & $\begin{array}{l}\text { Talea Ori strati- } \\
\text { graphic section* }\end{array}$ & Rethymno & 24.89056 & 35.39278 & Lithology & & National & S, A & Green \\
\hline 37 & $\begin{array}{l}\text { Spilaio Lera, Stav- } \\
\text { ros }\end{array}$ & Hania & 24.10289 & 35.59025 & Cave & Tourism & National & $\mathrm{S}, \mathrm{N}, \mathrm{C}$ & Yellow \\
\hline 38 & Spilaio Katholikoy & Hania & 24.14661 & 35.59025 & Cave & Tourism & National & $\begin{array}{l}\mathrm{A}, \mathrm{S} \\
\mathrm{N}, \mathrm{C}\end{array}$ & Yellow \\
\hline 39 & Tafkoura pothole & Rethymno & 24.85835 & 35.22222 & Cave & Science & National & $\mathrm{S}, \mathrm{N}$ & Green \\
\hline 40 & $\begin{array}{l}\text { Spilaio Ilithiias, } \\
\text { Elia }\end{array}$ & Irakleio & 25.23033 & 35.3301 & Cave & Science & National & $\begin{array}{l}\mathrm{A}, \mathrm{S} \\
\mathrm{N}, \mathrm{C}\end{array}$ & Green \\
\hline 41 & $\begin{array}{l}\text { Agia Paraskevi } \\
\text { cave, Skoteino }\end{array}$ & Irakleio & 25.29749 & 35.30488 & Cave & Tourism & National & $\begin{array}{l}\mathrm{A}, \mathrm{S} \\
\mathrm{N}, \mathrm{E}, \mathrm{C}\end{array}$ & Red \\
\hline 42 & $\begin{array}{l}\text { Sykias Spilios, } \\
\text { Zakros }\end{array}$ & Lasithi & 26.27803 & 35.11966 & Cave & $\begin{array}{l}\text { Tourism, } \\
\text { Science }\end{array}$ & National & $\begin{array}{l}\mathrm{A}, \mathrm{S} \\
\mathrm{N}, \mathrm{E}, \mathrm{C}\end{array}$ & Yellow \\
\hline 43 & $\begin{array}{l}\text { Trapeza cave, Tyli- } \\
\text { sos }\end{array}$ & Irakleio & 24.00122 & 35.31013 & Cave & Science & National & $\begin{array}{l}\mathrm{A}, \mathrm{S} \\
\mathrm{N}, \mathrm{C}\end{array}$ & Green \\
\hline 44 & Prinos Cave & Rethymno & 24.64587 & 35.39129 & Cave & & National & $\begin{array}{l}\mathrm{A}, \mathrm{S} \\
\mathrm{N}, \mathrm{C}\end{array}$ & Green \\
\hline 45 & $\begin{array}{l}\text { Zoure cave, } \\
\text { Azogyre }\end{array}$ & Hania & 23.70946 & 35.27168 & Cave & Tourism & National & $\mathrm{C}$ & Yellow \\
\hline 46 & $\begin{array}{l}\text { Skourdoulakia } \\
\text { cave, Asfentou }\end{array}$ & Hania & 24.17692 & 35.25064 & Cave & & National & S, C & Green \\
\hline 47 & $\begin{array}{l}\text { Mavro Skiadi pot- } \\
\text { hole, Melidoni }\end{array}$ & Hania & 24.07492 & 35.33576 & Cave & Science & National & $\mathrm{S}, \mathrm{N}$ & Green \\
\hline 48 & $\begin{array}{l}\text { Gourgouthakas } \\
\text { potohole }\end{array}$ & Hania & 24.08436 & 35.33465 & Cave & Science & National & $\mathrm{S}, \mathrm{N}$ & Green \\
\hline 49 & Kera active fault & Hania & 23.72889 & 35.46556 & Fault & & Regional & $\mathrm{S}$ & Green \\
\hline
\end{tabular}




\begin{tabular}{|c|c|c|c|c|c|c|c|c|c|}
\hline & Name & $\begin{array}{l}\text { Prefec- } \\
\text { ture }\end{array}$ & Lon & Lat & Category & $\begin{array}{c}\text { Human } \\
\text { Activities }\end{array}$ & $\begin{array}{l}\text { Impor- } \\
\text { tance }\end{array}$ & Value & $\begin{array}{l}\text { Con- } \\
\text { serva- } \\
\text { tion }\end{array}$ \\
\hline 50 & Topolia gorge & Hania & 23.68167 & 35.41083 & Landform & Traffic & Regional & $\mathrm{S}, \mathrm{A}$ & Green \\
\hline 51 & Ravdoucha Mines & Hania & 23.73083 & 35.52667 & Lithology & & Regional & $\mathrm{S}, \mathrm{C}$ & Green \\
\hline 52 & $\begin{array}{l}\text { Kampos folds and } \\
\text { boudinage }\end{array}$ & Hania & 23.56306 & 35.38667 & Fold & Traffic & Regional & $\mathrm{S}$ & Yellow \\
\hline 53 & $\begin{array}{l}\text { Agioi Theodoroi } \\
\text { boudinage museum }\end{array}$ & Hania & 23.61500 & 35.29222 & Fault, Fold & & Regional & $\mathrm{S}$ & Green \\
\hline 54 & Voutas detachment & Hania & 23.65583 & 35.28333 & Fault & Traffic & Regional & $\mathrm{S}$ & Green \\
\hline 55 & Rodakino gorge & Hania & 24.31417 & 35.20167 & $\begin{array}{l}\text { Fault, } \\
\text { Landform }\end{array}$ & Traffic & Regional & $\mathrm{S}, \mathrm{A}$ & Green \\
\hline 56 & $\begin{array}{l}\text { Koundoura Pa- } \\
\text { leorivages }\end{array}$ & Hania & 23.66735 & 35.23804 & Landform & & Regional & $\mathrm{S}$ & Green \\
\hline 57 & Agia Spring & Hania & 23.93194 & 35.47694 & Hydrology & Watering & Regional & E, N & Yellow \\
\hline 58 & Therissos Gorge & Hania & 23.99639 & 35.44278 & Landform & Tourism & Regional & $\mathrm{A}, \mathrm{N}$ & Green \\
\hline 59 & $\begin{array}{l}\text { Therissos } \\
\text { Blueschists }\end{array}$ & Hania & 23.97417 & 35.40278 & Lithology & & Regional & $\mathrm{S}$ & Green \\
\hline 60 & Vrysses paleoflora & Hania & 24.20083 & 35.36278 & Fossils & Mining & Regional & $\mathrm{S}$ & Yellow \\
\hline 61 & Imbros Gorge & Hania & 24.16639 & 35.21500 & Karst & Tourism & Regional & $\mathrm{A}$ & Green \\
\hline 62 & Askifou Plateau & Hania & 24.18250 & 35.29222 & Landform & Agriculture & Regional & $\mathrm{A}, \mathrm{E}$ & Green \\
\hline 63 & Aradaina Gorge & Hania & 24.05500 & 35.20194 & Karst & $\begin{array}{l}\text { Tourism, } \\
\text { Science }\end{array}$ & Regional & $\mathrm{A}$ & Green \\
\hline 64 & Agia Irini Gorge & Hania & 23.83944 & 35.31167 & Landform & Tourism & Regional & $\mathrm{A}, \mathrm{N}$ & Green \\
\hline 65 & Klados gorge & Hania & 23.91333 & 35.22972 & $\begin{array}{l}\text { Landform, } \\
\text { Karst }\end{array}$ & Science & Regional & $\mathrm{S}, \mathrm{A}$ & Green \\
\hline 66 & Omalos Plateau & Hania & 23.90556 & 35.33361 & Karst & $\begin{array}{l}\text { Agriculture, } \\
\text { Tourism }\end{array}$ & Regional & $\mathrm{A}, \mathrm{N}$ & Green \\
\hline 67 & $\begin{array}{l}\text { Leyka Ori Desert } \\
\text { and Craters }\end{array}$ & Hania & 24.09056 & 35,30944 & Karst & & Regional & $\mathrm{S}, \mathrm{A}$ & Green \\
\hline 68 & Zaros spring* & Irakleio & 24.91222 & 35.13917 & Hydrology & $\begin{array}{l}\text { Watering, } \\
\text { Tourism }\end{array}$ & Regional & $\mathrm{A}, \mathrm{E}$ & Green \\
\hline 69 & $\begin{array}{l}\text { Marathos detach- } \\
\text { ment* }\end{array}$ & Irakleio & 24.98306 & 35.34528 & Fault & Science & Regional & $\mathrm{S}$ & Green \\
\hline 70 & Voulismeno Aloni* & Irakleio & 25.01778 & 35.32972 & Karst & Science & Regional & S, A & Green \\
\hline 71 & $\begin{array}{l}\text { Rouvas forest and } \\
\text { Ag. Antonios } \\
\text { Gorge* }\end{array}$ & Irakleio & 24.90972 & 35.16722 & Landform & $\begin{array}{l}\text { Tourism, } \\
\text { Science }\end{array}$ & Regional & $A, N$ & Green \\
\hline 72 & $\begin{array}{l}\text { Aidonochori } \\
\text { Karst* }\end{array}$ & Irakleio & 24.89861 & 35.31333 & Karst & Agriculture & Regional & $A, S$ & Green \\
\hline 73 & $\begin{array}{l}\text { Sculpures of } \mathrm{Na} \text { - } \\
\text { ture, Chonos* }\end{array}$ & Irakleio & 24.89222 & 35.32833 & Karst & & Regional & $A, S$ & Green \\
\hline 74 & $\begin{array}{l}\text { Messara basin, } \\
\text { asteroussia klip- } \\
\text { pens }\end{array}$ & Irakleio & 24.94722 & 35.00278 & Landform & $\begin{array}{l}\text { Agriculture, } \\
\text { Tourism }\end{array}$ & Regional & A, S & Green \\
\hline 75 & $\begin{array}{l}\text { Fournofaraggo } \\
\text { fault }\end{array}$ & Irakleio & 25.04000 & 34.99139 & Fault & & Regional & S, A & Green \\
\hline 76 & $\begin{array}{l}\text { Agia Galini Con- } \\
\text { glomerates }\end{array}$ & Irakleio & 24.70583 & 35.11194 & Lithology & & Regional & $\mathrm{S}$ & Green \\
\hline 77 & Giouchtas horst & Irakleio & 25.14444 & 35.24000 & Fault & & Regional & $\mathrm{S}, \mathrm{A}, \mathrm{C}$ & Green \\
\hline 78 & Apostoli area & Irakleio & 25.29278 & 35.21833 & Fossils & & Regional & $\mathrm{S}$ & Green \\
\hline 79 & Arvi gorge & Irakleio & 25.38667 & 35.09500 & Landform & & Regional & $\mathrm{A}, \mathrm{N}$ & Green \\
\hline
\end{tabular}




\begin{tabular}{|c|c|c|c|c|c|c|c|c|c|}
\hline & Name & $\begin{array}{l}\text { Prefec- } \\
\text { ture }\end{array}$ & Lon & Lat & Category & $\begin{array}{c}\text { Human } \\
\text { Activities }\end{array}$ & $\begin{array}{l}\text { Impor- } \\
\text { tance }\end{array}$ & Value & $\begin{array}{l}\text { Con- } \\
\text { serva- } \\
\text { tion }\end{array}$ \\
\hline 80 & $\begin{array}{l}\text { Kastamonitsa } \\
\text { springs, kastelli } \\
\text { fault }\end{array}$ & Irakleio & 25.38444 & 35.19528 & Hydrology & Watering & Regional & $\mathrm{A}, \mathrm{E}$ & Green \\
\hline 81 & Aposelemis delta & Irakleio & 25.33139 & 35.33500 & Landform & & Regional & $\mathrm{N}$ & Green \\
\hline 82 & $\begin{array}{l}\text { Kalamayka Me- } \\
\text { teora }\end{array}$ & Lasithi & 25.63722 & 35.06639 & Landform & & Regional & $A, S$ & Green \\
\hline 83 & Katharon plateau & Lasithi & 25.56028 & 35.14056 & $\begin{array}{l}\text { Landform, } \\
\text { Fossils }\end{array}$ & Agriculture & Regional & S, A & Yellow \\
\hline 84 & Lastros Fault & Lasithi & 25.89639 & 35.15222 & Fault & & Regional & $\mathrm{S}$ & Green \\
\hline 85 & $\begin{array}{l}\text { Chonos LA- } \\
\text { SITHIou }\end{array}$ & Lasithi & 25.42778 & 35.19167 & Karst & & Regional & S, A & Green \\
\hline 86 & Milatos cave & Lasithi & 25.57803 & 35.30824 & Cave & Tourism & Regional & $\begin{array}{l}\mathrm{A}, \mathrm{S}, \\
\mathrm{N}, \mathrm{E}, \mathrm{C}\end{array}$ & Red \\
\hline 87 & $\begin{array}{l}\text { Agios Nikolaos } \\
\text { lake }\end{array}$ & Lasithi & 25.71722 & 35.19056 & Landform & Tourism & Regional & A & Green \\
\hline 88 & Lastros Gypsum & Lasithi & 25.89417 & 35.16417 & Lithology & Mining & Regional & E,S & Yellow \\
\hline 89 & Koufonissi island & Lasithi & 26.14000 & 34.94222 & Landform & & Regional & A, S, C & Green \\
\hline 90 & Kalavros beds & Lasithi & 25.96528 & 35.19194 & Lithology & & Regional & $\mathrm{S}$ & Green \\
\hline 91 & Itanos detachment & Lasithi & 26.26306 & 35.26750 & Fault & & Regional & $\mathrm{S}$ & Green \\
\hline 92 & $\begin{array}{l}\text { Death gorge, Zak- } \\
\text { ros }\end{array}$ & Lasithi & 26.25611 & 35.09861 & Karst & Tourism & Regional & $\mathrm{A}, \mathrm{C}$ & Green \\
\hline 93 & $\begin{array}{l}\text { Psiloritis Mts - } \\
\text { Panorama* }\end{array}$ & Rethymno & 24.89944 & 35.26750 & Landform & & Regional & A & Green \\
\hline 94 & $\begin{array}{l}\text { Agia Marina meta- } \\
\text { flysch }\end{array}$ & Rethymno & 24.88972 & 35.24528 & Lithology & & Regional & $\mathrm{A}, \mathrm{C}$ & Green \\
\hline 95 & Nida plateau* & Rethymno & 24.83528 & 35.20611 & $\begin{array}{l}\text { Karst, } \\
\text { Landform }\end{array}$ & Agriculture & Regional & $\mathrm{A}, \mathrm{N}$ & Green \\
\hline 96 & Mithia, Nida* & Rethymno & 24.87889 & 35.22222 & Lithology & & Regional & $\mathrm{S}$ & Green \\
\hline 97 & $\begin{array}{l}\text { Petradolakia, } \\
\text { Nida* }\end{array}$ & Rethymno & 24.86806 & 35.21667 & Karst & Agriculture & Regional & $\mathrm{S}, \mathrm{A}$ & Green \\
\hline 98 & Pisloritis summit* & Rethymno & 24.77028 & 35.22611 & Landform & & Regional & A & Green \\
\hline 99 & Patsos Gorge & Rethymno & 24.57389 & 35.25500 & Landform & Tourism & Regional & $\mathrm{A}, \mathrm{N}$ & Green \\
\hline 100 & \begin{tabular}{|l|} 
Spili sprigs \\
\end{tabular} & Rethymno & 24.53806 & 35.21972 & Hydrology & Watering & Regional & $\mathrm{A}, \mathrm{E}$ & Green \\
\hline 101 & Spili fault & Rethymno & 24.54556 & 35.20333 & Fault & & Regional & S,A & Green \\
\hline 102 & $\begin{array}{l}\text { Sellia, Ravdoucha } \\
\text { beds }\end{array}$ & Rethymno & 24.39306 & 35.20972 & Lithology & Trafic & Regional & $\mathrm{S}$ & Green \\
\hline 103 & Vatos scists & Rethymno & 24.54500 & 35.17472 & Lithology & & Regional & $\mathrm{S}$ & Green \\
\hline 104 & $\begin{array}{l}\text { Aktounda ophio- } \\
\text { lites }\end{array}$ & Rethymno & 24.54194 & 35.18861 & Lithology & & Regional & $\mathrm{S}$ & Green \\
\hline 105 & Carpholite schists & Rethymno & 24.53139 & 35.15472 & Lithology & & Regional & $\mathrm{S}$ & Green \\
\hline 106 & Preveli gorge & Rethymno & 24.47333 & 35.15306 & Landform & Tourism & Regional & $\mathrm{A}, \mathrm{N}$ & Yellow \\
\hline 107 & Amoudi notches & Rethymno & 24.41917 & 35.17167 & Landform & Tourism & Regional & S, A & Green \\
\hline 108 & Preveli blueschists & Rethymno & 24.46444 & 35.17500 & Lithology & & Regional & $\mathrm{S}$ & Green \\
\hline 109 & Kourtaliotis gorge & Rethymno & 24.46889 & 35.20333 & Landform & Traffic & Regional & S, A & Green \\
\hline 110 & Barroisitic rocks & Rethymno & 24.61528 & 35.20778 & Lithology & & Regional & $\mathrm{S}$ & Green \\
\hline
\end{tabular}




\begin{tabular}{|c|c|c|c|c|c|c|c|c|c|}
\hline & Name & $\begin{array}{l}\text { Prefec- } \\
\text { ture }\end{array}$ & Lon & Lat & Category & $\begin{array}{c}\text { Human } \\
\text { Activities }\end{array}$ & $\begin{array}{c}\text { Impor- } \\
\text { tance }\end{array}$ & Value & $\begin{array}{c}\text { Con- } \\
\text { serva- } \\
\text { tion }\end{array}$ \\
\hline 111 & $\begin{array}{l}\text { Balli Permian fos- } \\
\text { sils* }\end{array}$ & Rethymno & 24.77167 & 35.40889 & Fossils & & Regional & $\mathrm{S}$ & Green \\
\hline 112 & $\begin{array}{l}\text { Balli submarine } \\
\text { springs* }\end{array}$ & Rethymno & 24.78500 & 35.41056 & Hydrology & & Regional & $\mathrm{S}, \mathrm{A}$ & Green \\
\hline 113 & $\begin{array}{l}\text { Pantanassa forma- } \\
\text { tion }\end{array}$ & Rethymno & 24.61778 & 35.26250 & Lithology & & Regional & $\mathrm{S}$ & Green \\
\hline 114 & Metoxi bauxite* & Rethymno & 24.9037 & 35.28614 & Lithology & Traffic & Regional & $\mathrm{S}$ & Green \\
\hline 115 & Likotinara cave & Hania & 24.25889 & 35.3927 & Fossils & & Regional & $\mathrm{S}$ & Green \\
\hline 116 & Karoumpes caves & Lasithi & 26.27889 & 35.14102 & Fossils & & Regional & $\mathrm{S}$ & Green \\
\hline 117 & Kalo Chorafi cave & Rethymno & 24.84439 & 35.4075 & Fossils & & Regional & $\mathrm{S}$ & Green \\
\hline 118 & Simonelli cave & Rethymno & 24.43263 & 35.36829 & Fossils & & Regional & $\mathrm{S}$ & Green \\
\hline 119 & Koumpes caves & Rethymno & 24.44183 & 35.36743 & Fossils & & Regional & $\mathrm{S}$ & Green \\
\hline 120 & Agia Sofia cave & Hania & 23.68158 & 35.41105 & Cave & Tourism & Regional & $\mathrm{A}, \mathrm{S}, \mathrm{C}$ & Yellow \\
\hline 121 & $\begin{array}{l}\text { Panagia Ark- } \\
\text { oudiotisa Cave }\end{array}$ & Hania & 24.14381 & 35.58903 & Cave & Tourism & Regional & $\mathrm{S}, \mathrm{N}, \mathrm{C}$ & Yellow \\
\hline 122 & Kourna Cave & Rethymno & 24.28599 & 35.32063 & Cave & Tourism & Regional & $A, S, N$ & Yellow \\
\hline 123 & $\begin{array}{l}\text { Fantaxospiliara } \\
\text { cave }\end{array}$ & Rethymno & 24.64397 & 35.39283 & Cave & Tourism & Regional & $\begin{array}{l}\text { A, S } \\
\text { N, C }\end{array}$ & Yellow \\
\hline 124 & Hainlospilios cave & Irakleio & 24.926 & 35.30505 & Cave & Science & Regional & $\begin{array}{l}\mathrm{A}, \mathrm{S} \\
\mathrm{N}, \mathrm{C}\end{array}$ & Yellow \\
\hline 125 & Spilaio Doxas & Irakleio & 24.99893 & 35.34499 & Cave & Tourism & Regional & $\mathrm{A}, \mathrm{S}, \mathrm{N}$ & Yellow \\
\hline 126 & Honos cave, Sarhos & Irakleio & 24.985 & 35.221 & Cave & $\begin{array}{l}\text { Science, } \\
\text { Tourism }\end{array}$ & Regional & $\begin{array}{l}\mathrm{A}, \mathrm{S} \\
\mathrm{N}, \mathrm{C}\end{array}$ & Green \\
\hline 127 & $\begin{array}{l}\text { Thergiospilios } \\
\text { cave, Kavousi }\end{array}$ & Lasithi & 25.8346 & 35.12997 & Cave & Tourism & Regional & $\mathrm{A}, \mathrm{S}, \mathrm{N}$ & Yellow \\
\hline 128 & $\begin{array}{l}\text { Apoloustres cave, } \\
\text { Pafkoi }\end{array}$ & Lasithi & 25.98945 & 35.08805 & Cave & Tourism & Regional & $\begin{array}{l}\mathrm{A}, \mathrm{S} \\
\mathrm{N}, \mathrm{C}\end{array}$ & Yellow \\
\hline 129 & $\begin{array}{l}\text { Megalo Katofygi } \\
\text { cave }\end{array}$ & Lasithi & 26.03759 & 35.1006 & Cave & Tourism & Regional & $\mathrm{A}, \mathrm{S}, \mathrm{N}$ & Yellow \\
\hline 130 & Prassas fossils site & Irakleio & 25.19209 & 35.31524 & Fossils & Traffic & Regional & $\mathrm{S}$ & Yellow \\
\hline 131 & Vigla cave, Vianos & Irakleio & 25.36832 & 35.01012 & Cave & Tourism & Regional & $\mathrm{A}, \mathrm{N}$ & Green \\
\hline 132 & Mougri cave, Sises & Rethymno & 24.83675 & 35.39489 & Cave & Tourism & Regional & $\begin{array}{l}\text { A, S } \\
\text { N, C }\end{array}$ & Yellow \\
\hline
\end{tabular}

*Psiloritis Geopark geotopes 